\section{ETHICS OF TIMELINESS IN CONFUCIANISM ${ }^{1}$}

\section{Sarinya Arunkhajornsak ${ }^{2}$}

\begin{abstract}
By exploring Confucius' attitude towards time, change, and transformation in the "Analects", this paper aims to illustrate that temporality plays a crucial role in Confucian ethics. Confucius uses the notion of timeliness as an ethical guide in self-cultivation and moral practice in order to harmonize human beings with all the events of change. This paper argues that timely sagehood is a key quality of the junzi or "excellent person." To be a timely sage, a junzi must cultivate the virtue of yi. This paper presents a conceptualization of "yi" in the "Analects" and proposes that its meanings limited to "righteousness" and "appropriateness" in the sense of morality, legitimacy and justice, include a sense of timeliness, namely, the quality of timely action and the inner intellectual capacity of a junzi to evaluate and work out the appropriate course of an action in an actual situation.
\end{abstract}

\section{Introduction}

Among the issues that Warring State thinkers are interested in are time, change,

\footnotetext{
${ }^{1}$ This paper is developed from a chapter of my doctoral dissertation, "Cosmology and Ethics in Confucianism." I wish to express my special thanks to Assoc. Prof. Suwanna Satha-anand, my $\mathrm{Ph}$. D. thesis advisor, for her critical comments and valuable suggestions in editing this paper.

${ }^{2}$ Lecturer, Department of Philosophy, Faculty of Arts, Chulalongkorn University
}

and transformation. Daoism, especially Zhuangzi, emphasized explanation of these issues in metaphysical realities and indicated that understanding of these realities is important in Daoist living. On the other hand, in the Analects, Confucius did not directly explain the reality of time, change, and transformation in metaphysical terms. He manifested his understanding of these realities through observation of natural phenomena and emphasized the ethical importance of time, change, and transformation in the conception of the good life and human existence. ${ }^{3} \mathrm{He}$ asked what an appropriate attitude towards change and transformation would be, and how one should live ethically in a continuous process of change, in particular, the period of great disorder in which Confucius lived. In this paper, I will argue, on the basis of passages in Lunyi, or the Analects, ${ }^{4}$ that there is a cosmology of time and change grounded in the moral teachings of Confucius in the advocacy of selfcultivation, moral practice, and

\footnotetext{
${ }^{3}$ Passage 7:17 is usually interpreted as showing that Confucius grasped the reality of time and change from studying the Yijing or the Book of Changes during his later life. But in that period, the Yijing was basically taken to be a divination book. Moreover, there is a textual variant of passage 7:17 which $y i$ is written 亦 rather than 易. Although passage 13:22 contains a quotation from the Yijing, this passage is also problematic in claiming that Confucius was interested in the Yijing in whatever form of it during his life. (See also Van Norden 2007: 98).

${ }^{4}$ This paper used the Analects as translated by Edward Slingerland (Confucius 2003), except that key terms such as junzi, yi, and ren are not translated because I interpret them differently from Slingerland.
} 
appropriateness $(y i) .^{5}$ In other words, temporality is a necessary guide in Confucian ethics. For example, ethical cultivation should progress at different ages in a person's life. In the practice of benevolence (ren) and ritual (li), a primary consideration is not obedience to a strict moral rule but rather the timeliness of each situation, which differs in different contexts. For this reason, Confucian ethics can be called "ethics of timeliness" (Cheng 2003: 728-732), and Confucius was admired as a timely sage who acted in a timely manner and gathered together all that was good (Mencius 5B:1). Although temporality plays other roles in Confucian ethics, such as historical continuity, I discuss only the role of timeliness in selfcultivation and moral practice in a particular situation which involves the harmonization of human beings with a process of change.

This paper consists of three sections. I begin with a brief discussion of passage 9:17 which suggests that Confucius understood the reality of time and change from observing natural phenomena. Then,

\footnotetext{
${ }^{5}$ The study of the relationship between cosmology and ethics in the Analects has been reinvigorated by the excavation of the Guodian bamboo slips in 1993. These pieces of evidence have provided modifications to the cosmological view shared by classical Confucianism and Daoism. I propose in my dissertation that a correlation between the way of the cosmos or nature and morality appears in the Analects. Confucius' ethics is "Cosmoethics" which considers that the good life of an individual and the social world reflects a harmonization with nature or cosmos and the nature is the "source" of that morality. More detailed presentation of this broader issue will be discussed in another paper. See also, my doctoral dissertation, Cosmology and Ethics in Confucianism (Arunkhajornsak 2007)
}

I explain some common ground shared by Confucius and other Chinese thinkers on the idea of time. In the second section I will consider Confucius' attitude towards time, change, and transformation and introduce the notion of timeliness, which plays a crucial role in Confucian ethics. ${ }^{6}$ I propose that change and transformation in Confucian ethics can be grasped in both broad and narrow senses. In the broad sense, I mean change and transformation of natural and historical realities such as seasons, natural disaster, war, and political or economic chaos. In the narrow sense, I mean a particular situation and the life context of an excellent person (junzi) or a sage (shengren) who knows that these two senses of change and transformation are interdependent and are constantly interacting. For example, although war or political chaos may influence a junzi's life or fate (ming), causing him, for instance, to fail in his career or to lose a love one, he could use his virtue and wisdom to determine his life and to reform society. In order to avoid both hopelessness, as in the case of recluses, and an insistence on certainty or refusal to be flexible, the significant role of timeliness in selfcultivation and moral practice is to harmonize (he) one with the process of change in both senses.

\footnotetext{
${ }^{6}$ My discussion on the notion of timeliness in Confucius' ethics corresponds with the Confucian term shizhong which is found in The Mean or Zhongyong and is more clearly specified in the Mencius. As a noun, zhong means "middle" and "appropriate." As a verb, it relates to archery and means "to hit the target". Confucians use zhong with two meanings: "the middle or appropriate way between excess and deficiency" and "righteous appropriateness.” (Yu 2002: 342-350)
} 
However, the timeliness of an action is apparent not to everyone but only to a junzi. In the final section, I propose that a junzi can make appropriate judgments and perform appropriate actions because of his excellence in the virtue of appropriateness (yi). I offer a conceptualization of $y i$ in the Analects and propose that its meanings are not limited to "righteousness" and "appropriateness" in the sense of morality, legitimacy, and justice but include the sense of timeliness, namely, the quality of timely action and the inner intellectual quality of a junzi who acts in a timely manner. $Y i$ can be applied to both agents and acts, but some scholars have chosen to render $y i$ as the quality of an action justified by external moral principles such as $l i$ rather than to include the sense of the inner quality of a junzi. I argue that these views of $y i$ overlook its significant sense and the role it plays, which involves the dimension of temporality in Confucian ethics. Consequently, they do not lay adequate emphasis on the sense of $y i$ as a virtue of the intellectual capacity of a junzi to evaluate and formulate an appropriate course of action in a particular situation. Although following prescriptive rites implies $y i$ action, the intellectual capacity to judge why $l i$ should be followed in a particular situation is also important. For this reason, timely sagehood and the virtue of $y i$ are significantly related. ${ }^{7}$ At the end

7 Although I propose that Confucian $y i$ includes the sense of timeliness, this does not imply that it is the same as Zhuangzi's view of situational appropriateness. In Zhuangzi's view, moral standards are perspectival relativism in the sense of epistemological equality, therefore, situational appropriateness should not be restricted to any particular standard or perspective. In contrast, $y i$ in Confucian thought is appropriateness according to ren and $l i$. Moreover, virtue of $y i$ must be cultivated only in Confucian society. of this paper, I consider the case of Zaiwo's inquiry into reducing three-year mourning, which is an instance for understanding the virtue of Confucius' $y i$ as the quality of a timely sage.

\section{Time in Confucius and the classical Chinese perspective}

In The Way of Water and Sprouts of
Virtue, Sarah Allan argues,

Early Chinese thinkers, whatever their philosophical school, assumed that common principles informed the natural and human worlds. By studying nature one could understand humankind. Thus, the natural world rather than religious mythology provided the root metaphors for the formulation of many of the earliest Chinese philosophical concepts. (Allan 1997: 4)

She claims that one of the most natural things which Chinese thinkers used for formulating philosophical concepts was water (shui).

Water, with its multiplicity of forms and extraordinary capacity for generating imagery, provided the primary model for conceptualizing general cosmic principles, principles which applied to the behaviour of people, as well as to the forces of nature. (Allan 1997: 4)

In Classical Chinese, the idea of time was also conceptualized using the model of water. There is no Classical Chinese word equivalent in meaning to the English word time as it is usually interpreted. Passing time is represented by the imagery of a continuous stream of water and changing 
seasons (shi). ${ }^{8}$ In the Analects 9:17, Confucius, while standing on a riverbank, observed, "Look at how it flows on like this, never stopping day or night!" This passage not only suggests that Confucius compared the flowing stream with time and life passing, but also implies that he understood time and change by seeing water; that is, the events of change in his life and in the world were the same continuous process.

The view that Confucius understands the natural order and associates natural phenomena with moral guidance also appears in other passages. In 6:23, Confucius says, "The wise take joy in rivers, while the ren take joy in mountains. The wise are active, while the ren are still. The wise are joyful, while the ren are long-lived." Here, Confucius compares the dynamism of water and the stability of a mountain with the character of a wise person and a ren person, respectively. In 17:19, a similar idea appears:

The Master sighed, "Would that I did not have to speak!" Zigong said, "If the Master did not speak, then how would we little ones receive guidance from you?" The Master replied, "What does Heaven ever say? Yet the four seasons are put in motion by it, and the myriad creatures receive their life from it. What does Heaven ever say?"

\footnotetext{
${ }^{8}$ Although the word shi in the Chinese language nowadays is translated as "time", its original meaning is "season", "seasonality" and "timeliness". Shi is also meaningful in the context of a natural order to which people and other living things must correspond to achieve their goals and flourish. (Allan 1997: 10-13).
}

This passage suggests that the continuity of transmitting ritual and virtue via real actions resembles the continuity of the four seasons, which proceed well even though tian does not order than and even if no ruler accepts Confucius's saying.

It is noteworthy here that Confucius does not view time as a concept to be separated from concrete happenings in the world. In other words, "time is indeed to be identified with change and transformation of things. Thus to experience time is to experience concrete events of change" (Cheng 1974: 156). For this reason Confucius' notion of time involves qualitative differentiation within particular situations rather than determination of a general character of time.

Furthermore, ultimate reality is seen in Classical Chinese thinking as a process of creative transformation, and there is no separate transcendent world or reality of timelessness or eternity. In Confucian philosophy, tian is generally translated as "Heaven", but it is neither a timeless place nor anything like the concept of God in the Judeo-Christian tradition (Hall and Ames 1987: 11-25). Tian is "both what our world is and how it is" (Ames and Rosemont Jr. 1998: 47). ${ }^{9}$ The Great Dao, or the Way, in the metaphysics of Daoism

\footnotetext{
${ }^{9}$ Confucius decreased the anthropomorphic and fatalistic sense of tian, which had earlier been influenced by Zhou traditions, and emphasized the cultivation of virtue instead. Most scholars overlook the crucial role of tian in Confucius' philosophy, but I argue that passage 2:4 supports the opposite view. Therefore, to study Confucius' philosophy we must also consider tian in the Analects which should be understood as nature or cosmos rather than as God. See arguments in Cosmology and Ethics in Confucianism (2007: 27-42).
} 
is likewise not a reality to be transcended. Cheng argues, "If one can speak of transcendence of time, it is only to mean to identify oneself with the source of change or the power of change" (1974: 157). In Confucianism, it is described as participating in the creativities of Heaven and Earth, while in Daoism it is described as returning to the origin of change or nature (Dao) (Cheng 1974: 157)

Classical Chinese thinkers were concerned with how one should live in a process of change rather than how to go beyond it. Although both Confucianism and Classical Daoism, i.e., Lao-Zhuang, share certain metaphysical ideas about time, they propose different attitudes towards change and transformation (Chan 1977: 135-136). In Daoism, the world is involved in a continuous process of change without "a beginning" or "an end". Rather than separating "being" from "non-being", one should forget separation and enjoy life with the transformation of the world. Confucianism emphasizes a qualitative differentiation of each moment or period of time and regards change and transformation positively as a creative process. The world is a place of continuous multiple creations. If disorder occurs in nature or in the human world, this is a sign that the creative process has been interrupted by human behavior. Therefore, to avoid disorder, one must harmonize (he) humanity with Heaven and Earth through moral practice.

\section{Temporality in Confucian Ethics}

The philosophical questions that occupied Confucius' mind concerned not only what the Way (Dao) of a good life is but also how one should live in a continuous process of change, in particular, in the period of great disorder in which
Confucius lived, which represents one of the most terrible times in human history. Classical Chinese thinkers considered how one should exist in such uncertain and dangerous time. The Analects presents the suggestion of the recluses (yinzhe), primarily Daoists, that the human world is inundated like floodwaters and the whole world is in chaos, so one should let everything go and leave the world rather than insist on changing it. They saw Confucius' attempts as an indication of stubbornness. Confucius argued, "A person cannot flock together with the birds and the beasts. If I do not associate with the followers of men, then with whom would I associate? If the Way were realized in the world, then I would not need to change anything" (18:6). He rejects the recluses' suggestion because to exist within a process of change is neither to abandon the world and wait for destiny (ming) without doing anything nor to insist on certainty and to refuse to be flexible (9:4). Disorder is caused by the immoral conduct of human beings, not by natural forces. It is necessary for human beings, who cannot associate with birds and beasts, to change the world by putting the Way, or the Dao, on course in the world again. Confucius believed that, with one change, the world can attain the Way: "With a single change, Qi could measure up to Lu. With a single change, Lu could attain the Way" (6:24). The "single change" means the ruler should accept Confucius'philosophy and employ him in government as he was confident that "if someone would simply employ me, within a single year I could put things into some kind of order, and within three years the transformation would be complete" $(13: 10)$.

However, the next question is how can we know or justify whether our actions 
initiate the "right" process of change. There is a paradox in Confucius's reformist agenda, namely, how could Confucius explain his untimely struggle? How could he resolve the conflict between his personal ideals and historical reality? Rui Zhu has proposed that Confucius solved this paradox via the notion of timeliness. He says, "Confucius believes that it is timely for him to make the untimely effort ... Although his exertion may be untimely in terms of its social efficacy, it is always timely, Confucius teaches, for a junzi to exemplify the good" (Zhu 2006: 130-131). I would like to argue that Confucius not only considers timeliness from the good action of a junzi but also proposes that timeliness indicates the attitude of a junzi towards change and transformation. There are two senses of change and transformation in Confucian ethics. In the broad sense, change and transformation are grasped as natural and historical realities which form influential conditions for human lives and seem to be accepted as fate or destiny. This is the case for events such as death, accidents, natural disasters, and war. In the narrow sense, change and transformation are grasped as the particular situation and life context of a junzi or sage, who knows that both senses of change and transformation are interdependent and constantly interacting. In other words, events of change in individual lives originate and depend on events of change in the world and vice versa. For these reasons, Confucius' statements that one has no way of becoming a junzi unless one understands destiny (ming) (20:3) and the decrees of heaven (tianming) (2:4) indicate that knowing ming is not equivalent to foreseeing predestination; it is an understanding that events of change in one's life are not separable from tian, which is the source or the whole process of change, while, at the same time, one is also aware of the significance, the role, and the capacity which one can determine in one's own life. For example, in passage 12:5, Sima Niu laments that "Everyone has brothers, I alone have none" because his brother, Huan Tui, threatened Confucius' life. Zixia said to him,

I have heard it said, "Life and death are governed by fate, wealth and honor are determined by Heaven." A junzi is respectful and free of errors. $\mathrm{He}$ is reverent and ritually proper in his dealings with others. In this way, everyone within the Four Seas is his brother. How could a junzi be concerned about not having brothers?

Zixia here suggests that Sima Niu, rather than refusing unalterable brotherliness as a factual condition, redefines the meaning of brotherhood from blood relationship to a moral criterion; that is, Sima Niu could change his life by determining his own ming. Therefore, in solving a paradox in the notion of timeliness, Confucius understands his ming in the sense of the uncontrollable condition that the failure and success of reformation depend on historical contexts, while, at the same time, he also recognizes that changing the world by the Dao also depends on how he determines his ming. For this reason, it is appropriate $(y i)$, in the sense of timeliness, for him to make a consistent effort to change the world, and thus, later in life, he adjusted his life and became a teacher.

Hence, the notion of timeliness not only provides a solution to the paradox between Confucius' personal ideals and historical reality, but, also plays a significant role in Confucian ethics. In other words, Confucius, as a timely sage, employs the 
notion of timeliness to harmonize human beings with a process of change in different focuses and fields of the natural world, the human world, and an individual's life through the teachings of self-cultivation and moral practice.

Confucius acknowledged that moral cultivation and wisdom are developed by exerting oneself, and not everyone is able to cultivate him-/herself. There are people who do not recognize the value of selfcultivation or who do not pay enough attention to learning and do not constantly ask themselves, "What should I do? What should I do?" (15:16). Thus, Confucius emphasized ways to improve morality and wisdom rather than the physical body. ${ }^{10}$ $\mathrm{He}$ advocated that ethical cultivation should follow the procedure of "Set[ing] your heart upon the Way, rely[ing] upon Virtue, lean[ing] upon ren, and explore widely in your cultivation of the arts" (7:6). "Set[ing] your heart on the Dao" implies initial commitment, de is a

\footnotetext{
${ }^{10}$ The meaning of physical body here is nurturing for physical well-being or pleasure and nourishing the vital force or qi. But, later, the other Confucians associated $q i$ with moral cultivation and conduct. Those such as Mencius thought of $q i$ as a motivation and a source of moral practice (Mencius 2A:2). He was interested in the relationship of $q i$, heartmind (xin), and morality because one of the philosophical questions discussed during the fourth century B.C. by Chinese thinkers was whether devotion to nourishing the body corresponded to human nature (renxing), as was anticipated by Yang Zhu. Only in passage 16:7 of the Analects does the word qi appear unconnected with moral cultivation or, rather, the suggestion to display careful vigorous conduct. For Confucius, moral cultivation included control of the body's performance, such as countenance and posture, to express $l i$, rather than control of qi.
}

resource, ren is an ideal to be approached and the arts serve as relaxation after personal accomplishment (Brooks and Brooks 1998: 40). ${ }^{11}$ Nevertheless, to practise these procedures will take time because ethical cultivation must progress along with biological maturation continuously from childhood on. Confucius described his ethical development in the following: "At fifteen, I set my mind upon learning; at thirty, I took my place in society; at forty, I became free of doubts; at fifty, I understood Heaven's Mandate; at sixty, my ear was attuned; and at seventy, I could follow my heart's desires without overstepping the bounds of propriety" (2:4). Although this passage reflects Confucius' self-assessment, it can be taken as a model or a guideline for motivating oneself in ethical cultivation, suggesting the long process of making progress at different stages in one's life.

However, it is not necessary to make progress or to accomplish things at the same age as Confucius because the intentions and capacities of each person are not identical. Confucius said,

\begin{abstract}
"those who are born understanding it are the best; those who come to understand it through learning are second. Those who find it difficult to understand and yet persist in their studies come next. People who find it difficult to understand but do not even try to learn are the worst of all." (16:9)
\end{abstract}

\footnotetext{
${ }^{11}$ The arts not only serve as relaxation "after" accomplishment but are also a means of ethical cultivation. Additionally, ethical and aesthetic knowledge are not separable in Confucian ethics.
} 
For this reason, Confucius considered timeliness in ethical progress from the particular conditions of an individual in addition to progress at different ages. For example, Zilu and Ranyou asked Confucius the same question: whether one should immediately practise what one has heard. Confucius answered them in different ways by considering their distinctive characters. Zilu had the energy of two, so Confucius sought to rein him in by suggesting that, since his father and elder brothers were still alive, he should confer with them before making a decision. Since Ranyou was diffident, Confucius urged him on to practise immediately (11:22). Understanding the distinctive qualities of each person, Confucius emphasized the love of learning (haoxue) rather than the expectation of particular accomplishments. He believed that if one devoted oneself to learning and "Set [one's] heart on the way", ren was not at all remote $(7: 30)$.

The role of timeliness is also a guideline in the evaluation of one's ethical progress and moral worth. In the Analects, someone asked Confucius whether the youth from Que village who carried messages for Confucius was making any progress. Confucius said, "I observed him sitting in the presence of adults, and also walking alongside his elders. He is not looking to improve himself, but is just after quick success" (14:44). The questioner possibly thought the youth was making quick progress in his career, noticing the youth's closeness with senior and elder officers, but Confucius thought that the most important progress the youth should concern himself with was learning and moral cultivation. The youth from Que was not making ethical progress appropriate to his age. He was merely imitating adulthood without ethical cultivation.

Furthermore, Confucius comments, "We should look upon the younger generation with awe because how are we to know that those who come after us will not prove our equals? Once, however, a man reaches the age of forty or fifty without having learned anything, we can conclude from this fact alone that he is not worthy of being held in awe" (9:23). Confucius assumed that, by the time one reaches forty to fifty years of age, one must have been adequately cultivated in morality and wisdom and must have had enough time to accumulate some ethical, cultural, and political achievements. Moral cultivation in the long years of a person's life is an indication of his moral worth. To those such as Yuanrang, who sat waiting on the floor with his legs spread wide, Confucius said, "A young man devoid of humility and respect for his elders will grow into an adult who contributes nothing to his community. Growing older and older without the dignity to pass away, he becomes a burden on society" (14:43). This passage suggests that self-cultivation cannot begin at an advanced age and that anyone who has not passed on anything worthwhile by that age is a hopeless person.

However, Confucius limited the certain age for the case of hopeless person, he said, "if, having reached the age of forty, you still find yourself despised by others, you will remain despised until the end of your days" (17:26). To be disliked by others in this passage does not mean to be despised by the worst villagers (13:24). One must look into the matter carefully $(15: 28)$. Confucius indicates that he is speaking of those who are despised by people for their immorality. It is possible 
that those who have done nothing worthwhile by age forty to fifty are not immoral persons. It could be that they have simply accumulated an inadequate number of admirable achievements. On the other hand, if a person is still despised at age forty, it suggests that he or she has probably neglected many chances to change him-/herself and has seldom behaved morally to the others so that he or she deserves "to be disliked". So, Confucius considers it hopeless to change such a person.

It seems that proper age is not only a condition for guiding the way of ethical progression. Conversely, cultivation of morality is also a condition for having a proper life span. Confucius said, "The wise $\left(z h i^{\mathrm{a}}\right)$ take joy in rivers, while the ren take joy in mountains. The wise are active, while the ren are still. The wise are joyful, while the ren are long-lived" (6:23). He believed that ren persons live long because they live harmoniously and peacefully and support others. Consequently, they rarely encounter improper destinies such as dying in fetters (see Lau 1970: 7A: 2). Nevertheless, longevity does not guarantee moral worth. Indeed, there are ethically accomplished persons who die at a young age due to uncontrollable ming such as illness or unexpected accidents. For instance, Yan Hui was the only disciple commended by Confucius as a person who truly loved learning and was excellent in cultivating ren but, unfortunately, his allotted span was too short. Confucius accepted that such unfortunate destinies could befall a person such as Yan Hui, so he compared Yan Hui's death to the case of seedlings that do not flower or flowers that do not bear fruit $(9: 22)$.

Timeliness in Confucian ethics also indicates the harmonizing process of moral practice with events of change in the world. Confucian ethics is not rule-based ethic. A primary consideration in practising ren and $l i$ is not insistence on following strict moral rules; rather, great emphasis in placed on flexibility of practice in different contexts. For instance, when Meng Yizi asked about filial conduct (xiao), Confucius said, "Do not disobey." This meant, "When your parents are alive, serve them in accordance with the rites; when they pass away, bury them in accordance with the rites and sacrifice to them in accordance with the rites" (2:5). But the injunction "Do not disobey" does not require one to follow one's parents in everything on all occasions. If presents act wrongly, then in some situations the son and the daughter can remonstrate with them gently (4:18).

Another example appears in passage 9:3 where Confucius follows the accepted practice of $l i$ by using a silk cap instead of the hemp cap that is prescribed by the ritual book because the change of material does not destroy the essence of the ceremonies. Agriculture was a major occupation in that period. It was possible that some natural disaster might produce poverty, so Confucius allowed people to take frugality into consideration rather than insisting on prescriptive rites. However, with respect to kowtowing only after ascending to the throne, Confucius did not support this accepted $l i$ practice because it destroyed the deference shown by the original practice wherein people had to kowtow upon entering the hall. In these instances, ren and $l i$ practice could be flexible, except when it demolished the spirit of ren (loving and caring for others) or the harmony (he) of society. We must cooperate in changing some practices as 
Confucius did, even though they may be generally accepted. ${ }^{12}$

In the Analects, time and change are not topics discussed in the abstract. Confucius' experiences of and responses to different situations and the passages related to tian and ming in the Analects can be a source for exploring his attitude towards time and change. His basic ideas consist of recognition that all changing events are interdependent and constantly interacting and that human beings should live with change harmoniously. These attitudes are manifested through the notion of timeliness as an ethical guide in selfcultivation and moral practice. However, timeliness of action is apparent not to everyone but only to a junzi or a sage who is morally excellent and has the wisdom $\left(z h i^{\mathrm{a}}\right)$ to measure (quan) situations. In the next section, I will consider the relationship of the junzi's virtue of $y i$ and his timely flexibility in different situations. ${ }^{13}$

\section{Timely action and judgment of the Junzi and the virtue of $Y i$}

In the Analects, Confucius makes several remarks concerning categories of individuals who show great achievement such as sages (shengren), excellent persons (junzi), scholar-officials $\left(s h i^{\mathrm{a}}\right)$,

\footnotetext{
12 The proper period of time is also a condition for creating $l i$, as in passage 17:21, which contains Zaiwo's inquiry for reducing the three-year mourning period, which I will discuss in the last section.

${ }^{13}$ To cultivate the virtue of $y i$, a junzi must devote a long time to studying the examples of situational responsiveness and flexibility of ancient sages and to practicing in their own real situations. Discussion of how to cultivate this virtue is not the main point of this paper.
}

great persons (daren), complete persons (chengren), humane persons (renren or renzhe), and so on. Although becoming a shengren is the loftiest goal in Confucian ethics, Confucius believed that the highest goal that can practically be attained by ordinary people is to become a junzi, not a shengren. ${ }^{14}$ Even in his personal achievements, Confucius did not rank himself as a sage (7:34). He said that he would never get to meet a sage but would be content to meet a junzi $(7: 26)$. While Mencius and Xunzi espouse the greater goal that anyone can become a sage like Yao and Shun if s(he) engages in constant self-cultivation, Cua observes that, in Confucius' mind, the ideal of sagehood functioned as an abstract ideal of a perfect moral personality (Cua 2003: 329).

In general, the junzi is a morally and aesthetically excellent person whose quality of life acts as a model or guide for ordinary moral agents (Cua 2003: 331). In ancient literature prior to the time of Confucius, junzi meant "the son of a ruler", denoting nobility of birth and rank without necessarily indicating a morally excellent person. Confucius did not replace the political connotations of this term with moral qualifications but redefined them in such a way that moral cultivation had to correlate with sociopolitical participation (Hall and

\footnotetext{
${ }^{14}$ It is noteworthy that the category of humane (ren) person comprises part of the highest goal for ordinary people because certain passages use the words junzi and renren or renzhe interchangeably. Although passage 14.6 seems to suggest that the category of "renzhe" is higher than junzi, it is made clear elsewhere that the virtue of ren is a necessary condition for becoming a junzi. Moreover, passage 6:29 suggests that a junzi must also have wisdom, while a renzhe may have only ren (see also Hall and Ames, 1987: 187-188).
} 
Ames 1987: 183). For Confucius, "junzi is a qualitative term denoting someone who has an ongoing commitment to personal growth as expressed through the activities of self-cultivation and sociopolitical leadership" (Hall and Ames 1987: 188).

The various translations of junzi as "superior man", "gentleman", "nobleman", "paradigmatic individual", "exemplary person" and "excellent person" indicate the complexity of this notion. Different translations indicate which significant dimensions of meaning the translator would like to emphasize. For example, translating junzi as "gentleman" focuses on the junzi's embodiment of a cultural lifestyle (Cua 2003: 331) Translating it as "paradigmatic individual" focuses on the junzi's role in moral education (Cua 1992). In this paper, I choose to render junzi as "excellent person" because I would like emphasize the junzi's excellence in the virtue of $y i$, which qualifies him as a timely, flexible person in addition to being a broad-minded, just, and harmonybuilding individual. Confucius said, "The junzi understands $y i$, whereas the petty person understands profit" (4:16). Petty persons are concerned with personal advantage; they are easily agitated and anxious (7:37); they are partisan, but they do not associate openly with others (2:14); they seek sameness rather than harmony (13:23). On the other hand, junzi are concerned with $y i$ : they are calm and unperturbed, they associate openly with others but are not partisan, and they always seek harmony.

In Confucian ethics, $y i$ is, together with ren and $l i$, a significant ethical ideal. Confucius said, "The junzi admires $y i$ above all" (17:23) and "With regard to the world, the junzi has no predispositions for or against any person. He merely associates with those he considers $y i$ " (4:10). However, $y i$ is a difficult concept because the word $y i$ occurs only twentyfour times in the Analects and no passage offers elaboration or a clear definition.

In general, $y i$ is translated as "right" "righteousness" and "moral" (Van Norden 2002: 27). Etymologically, it relates to $y i^{\mathrm{a}}$, which means "appropriate" "fitting". The character $y i$ consists of the ideograph for a sheep (yang) over the first-person pronoun (wo), represented by a human hand holding a dagger-axe ( $g e$ ). Hence, yi can be interpreted as the attitude one has in "making oneself a sacred representative of the community and thereby purifying and making appropriately sacred the sacrificial animal" (Ames and Rosemont 1998: 54). Although I choose, in this paper, to render $y i$ as "appropriateness", which causes closer to the etymological sense than do "moral" or "morality" (Ames and Rosemont 1998: 53-54), it is noteworthy that the meanings of $y i$ have more than one dimension. Satha-Anand proposes that $y i$ appears in three senses in the Analects (2008: 322). Firstly, it indicates appropriateness or righteousness in the sense of moral conduct. For example, "Trustworthiness comes close to $y i$, in that your word can be counted upon" (1:13), and "To see what is $y i$, but to fail to do it, is to be lacking in courage" (2:24). Secondly, it means appropriateness or righteousness in the sense of the legitimacy of a ruler, as when Confucius says, "Eating plain food and drinking water, having only your bent arm as a pillow-certainly there is joy to be found in this! Wealth and eminence attained inappropriately (buyi) concern me no more than the floating clouds" (7:16). Thirdly, it points to appropriateness or righteousness in the sense of just or fair governance, as in when Confucius remarks that 
appropriateness (yi) in employing the services is one of the ways of a junzi $(5: 16)$.

Although $y i$ is used in different senses, its most significant role, in my view, is its sense of preventing the junzi's insistence on certainty and making the junzi flexible in different situations. To return to one of Confucius' statements given above, "With regard to the world, the junzi has no predispositions for or against any person. He merely associates with those he considers $y i "$ (4:10). To do what is appropriate or right in any particular circumstance is not just a matter of conformity to ren and $l i$ but also of appropriate discernment or judgment of relevance in actual situations. Cua compares the virtue of $y i$ with $l i$, saying that "If $l i$ defines an aspect of right act in ren-morality, it is an emphasis on the tie between actions and the cultural lifestyle. $Y i$, on the other hand, gives us a sense of rightness as relating to the concrete, problematic situation that calls for action inspired by ren" (Cua 2003: 333). For this reason, the meanings of $y i$ include, in my view, appropriateness in the sense of timeliness, e.g., the quality of timely action, and the inner intellectual quality of a junzi who acts in a timely manner.

The next important point of discussion is that $y i$ in the Analects can be understood both as the quality of an action justified by external moral standards such as $l i$ and the inner intellectual quality of an agent who performs appropriate acts. In other words, $y i$ can be understood as being "what is appropriate to do" and "the intellectual quality of judging and doing what is appropriate" (Yu 2006: 336). For example, The following passages show that $y i$ refers to a standard for right conduct which is contrary to profit $\left(l i^{\mathrm{a}}\right)$ : "That I fail to cultivate Virtue, that I fail to inquire more deeply into that which I have learned, that upon hearing what is $y i$ I remain unable to move myself to do it, and that I prove unable to reform when I have done something wrong - such potential failings are a source of constant worry to me" (7:3). "To submit to fate when confronted with danger, to think of $y i$ when presented with an opportunity for gain, to focus on respectfulness when offering sacrifices, and to concentrate upon your grief when in mourning-these are the qualities that make a scholar-official acceptable" (19:1). In contrast, another of Confucius' sayings indicates that $y i$ comprises a junzi's disposition: "The junzi takes $y i$ as his substance $\left(z h i^{\mathrm{n}}\right)$, puts it into practice by means of ritual, gives it expression through modesty, and perfects it by being trustworthy. Now that is a junzi!" (15:18). The term $z h i^{\mathrm{n}}$ literally means "basic stuff." However, here it does not involve the notion of human nature, or renxing; it refers instead to the cultivated second nature of a junzi. The understanding of $y i$ as both the quality of an action and the intellectual capacity of agent raises questions of how they relate to each other and which is the more important: cultivating one's ethical nature or being a junzi who acts in a timely manner.

Some Chinese scholars have chosen to render $y i$ as a quality of an action justified by external moral principles rather than including the sense of the inner intellectual quality of a junzi. According to Lau, yi can be rendered as "right" or "duty". When used in a general sense, it is rendered as "moral" or "morality." But $y i$ is different from other ethical terms such as benevolence or ren. Basically, ren refers to the character of an agent and has more to do with disposition and motive than objective circumstances. Conversely, $y i$ 
represents a quality of acts which depends on their being morally fitting in particular circumstances rather than on the disposition or the motives of an agent. Although Confucian ethics is an agentethics, Confucius explicitly assumes that " $y i$ is the standard by which all acts must be judged while there is no further standard by which $y i$ itself can be judged" (Lau 1979: 27). Therefore, Lau affirms, "We can say, then, that in Confucius' moral system, although benevolence occupies the more central position, $y i$ is, nevertheless, more basic" (Lau 1979: 27).

Like Lau, Cheng holds that " $y i$ is a fundamental principle of morality that confers qualities of right and wrong on human actions and that produces a situation which intrinsically satisfies us as moral agents" (Cheng 1991: 233-234). Moreover, he thinks that Confucius takes $y i$ to be the basis and foundation of all virtues. If the disposition of a character lacks $y i$, it will not be a virtue (Cheng 1991: 234-235). Confucius said, "a junzi who is bold yet is lacking a sense of $y i$ will be unruly, while a petty person of the same cut will be a thief." (17:23)

The problem with the explications of Lau and Cheng is that, if $y i$ is a principle which is more fundamental than ren as Lau has affirmed, then an explanation is needed as to why $y i$ occurs in the Analects far less often than ren and why none of the disciples raised the question of $y i$. Cheng offers the explanation that "Confucius and his disciples have taken the notion of $y i$ for granted and that they assumed a universal and clear understanding of what constitutes $y i$ and its roles in formulating and specifying the norm and end of human conduct. Therefore they had no need for clarification" (Cheng 1991: 233). But if yi is a universal moral principle, the inevitable questions then become what this principle is and how we can come to know it. Lau thinks that $l i$ is such a principle because there is an intimate relationship between $l i$ and $y i$. If $l i$, or the rule of conduct, is based on $y i$, or moral principles, it is not merely following convention or subjective rules, and yi must be exemplified by $l i$ to be put into effect; otherwise, it is unclear how $y i$ can be known. Lau concludes, "Thus, while a rule can remain right only if it is constantly measured against the demands of principles, a principle cannot do without rules if it is to be put into effect. This dialogue between rules and principle constitutes the essence of Confucius' moral thinking" (Lau 1979: 50).

Hansen (1992: 82), like Lau, thinks that Confucius does not distinguish $l i$ from $y i$. Evidence for this argument is found in passage 13:18, where the Governor of She says to Confucius, "Among my people there is one we call "Upright Gong." When his father stole a sheep, he reported him to the authorities." Confucius replied, "Among my people, those who we consider "upright" are different from this: fathers cover up for their sons, and sons cover up for their fathers. "Uprightness" is to be found in this." Hansen interprets the phrase "among my people" as "Confucius thinks of $y i$ as a convention, as mores rather than moral reasoning" (Hansen 1992: 82).

If Lau and Hansen are correct, appropriate actions simply involve following prescriptive rites. But I would argue that the action of $y i$ requires more than merely following $l i$ because Confucius does not think that $l i$ constitutes the ethical guiding rules for conduct on all occasions. There are some cases where a junzi can act appropriately even though he is not 
following $l i$. For example, when a ruler came to see Confucius when Confucius was ill, neither forcing the weak body to receive the guest nor doing nothing to show respect was an appropriate action. Thus, Confucius performed respectfully by reclining with his head facing east and with his court dress draped over him with the sash drawn (10:19). Moreover, in the aforementioned passage 13:18, Confucius argues with the Governor of She that an "upright person" is not one who is truthful to authority of state at the expense of the relationship between father and son, rather than arguing that truthfulness depends on conventional $l i$.

The problem with all these views is that they tend to overlook the significant sense and role of $y i$ involved in the dimension of temporality in Confucian ethics. Consequently, they do not place adequate emphasis on $y i$ as a virtue of the intellectual capacity of a junzi. Although following prescriptive rites implies $y i$ action, the intellectual capacity to evaluate and judge why $l i$ should be followed in an actual situation is also important. I would like to propose not only that $y i$ be understood as a quality of an action or of an agent but that the sense of the inner intellectual quality of a junzi should be more adequately emphasized, because a judgment of timely action depends on the $y i$ of a junzi, which is the intellectual capacity to evaluate and judge what conduct will conform to ren and $l i$ in an actual situation, including the case of what $l i$ should be followed, how the $l i$ should be changed, and how one can behave virtuously in a particular situation which is not included in li. For these reasons, timely sagehood and the virtue of $y i$ are significantly related.
As the role of $y i$ involves practical reasoning, a view has arisen that $y i$ corresponds, in many respects, to Aristotle's theory of practical wisdom. Yu thinks that $y i$ is not simply practical rationality that places no ethical constraints on its target but that it is rather, a virtue of rational ability with a noble end (Yu 2006: 338-340). Furthermore, he compares Confucius's concept of $y i$ and $z h i$, or wisdom, with Aristotle's theory of practical wisdom in the sense that they share similar ideas regarding the conditions for an agent to perform a virtuous action: These conditions are that (1) the agent must have knowledge, (2) the agent must choose the act for its own sake, and (3) the action must flow from a certain character. For this reason, $y i$ is related to $z h i$. Zhi is both theoretical knowledge and practical knowledge, while $y i$ is the agent's ability to choose and determine the noble end (Yu 2006: 342).

To elucidate $y i$ as the virtue of the intellectual capacity of a junzi, let us briefly consider Zaiwo's inquiry for reducing the three-year mourning period, which is the clearest case for understanding Confucius' virtue of $y i$ as timeliness;

Zai Wo asked about the three-year mourning period, saying, "Surely one year is long enough. If the junzi refrains from practicing ritual for three years, the rites will surely fall into ruin; if he refrains from music for three years, this will surely be disastrous for music. After the lapse of a year the old grain has been used up, while the new grain has ripened, and the four different types of tinder have all been drilled in order to rekindle the fire. One year is surely long enough." 
The Master asked, "Would you feel comfortable then eating your sweet rice and wearing your brocade gowns?"

"I would."

The Master replied, "Well, if you would feel comfortable doing so, then by all means you should do it. When the junzi is in mourning, he gets no pleasure from eating sweet foods, finds no joy in listening to music, and feels no comfort in his place of dwelling. This is why he gives up these things. But if you would feel comfortable doing them, then by all means you should!"

After Zai Wo left, the Master remarked, "This shows how lacking in ren this Zai Wo is! A child is completely dependent upon the care of his parents for the first three years of his life-this is why the three-year mourning period is the common practice throughout the world. Did Zai Wo not receive three years of care from his parents?" $(17: 21)$

Zaiwo gives excuses for reducing the period of mourning by referring to the correspondence of a full year's mourning with the changing seasons and the continuous practice of $l i$ and music. Obviously, the reasons for his asking whether $l i$ can be flexible in different circumstances are the same reasons for Confucius following accepted the $l i$ practice using a silk cap. But Zaiwo's proposal is not appropriate because he only thinks of the flexibility of ritual without considering whether a full year's mourning would destroy the way of human family relationships, which form the root of a humane community, as filial piety is something that distinguishes human beings from animals. Confucius considers the ritual of three years' mourning period for one's parents appropriate filial conduct in light of the intimate relationship one has with one's parents because it corresponds to the three years of nurturing parents provided before an infant can leave their bosom. Furthermore, it is commensurate with the grief and the devastating feeling of losing one's parents. Confucius asked Zaiwo if he would feel comfortable eating fine rice and wearing colourful brocade after only one year's mourning because Confucius believed that Zaiwo had been nurtured by his parents for three years just like other infants and that he would be uncomfortable. But Zaiwo gave the opposite answer. Confucius did not pursue the matter but demend Zaiwo to be deficient in ren. Zaiwo lacked sensibility in graded relationships, which is the key quality of a ren person. This passage suggests that Confucius did not follow the ritual of three-year mourning without evaluating appropriateness in an actual situation by referring to seasonal changes and the continuous practice of $l i$ and music. Confucius used his intellectual capacity to determine that the appropriate period for mourning should be grounded in human biology and the intimate relationship between parent and son rather than other circumstances.

This passage also suggests that a junzi must know the reality of nature. When he chooses or changes a ritual, sets a certain age in moral development, or acts timely in particular situation, he considers harmonization with movements of nature in addition to the spirit of ren and harmony of society. This point also appears in passage 15:11, wherein Confucius chooses to adopt the calendar of 
Xia. The calendar of Zhou was suitable for astronomy, while the calendar of Xia was suited to the needs of farmers by providing instructions on what to do in accordance with the seasonal cycles. (Confucius 2003: 178). Although both calendars corresponded to movements of nature, Confucius followed the calendars of Xia because it also corresponded with the agricultural life-style of the people. Therefore, adopting the calendar of Xia helped humanity harmonize with Heaven and Earth.

In conclusion, Confucius thought that one can have a good life within the process of change in the world by living a moral life which harmonizes humanity with Heaven and Earth without neglecting the ways of human beings. This paper argues that temporality, especially timeliness, plays a significant role in Confucian ethics as expressed in the relationship between timely sagehood and the virtue of $y i$.

\section{References}

Allan, Sarah. 1997. The Way of Water and Sprouts of Virtue. New York: State University of New York Press.

Ames, Roger T., and Henry Rosemont Jr. 1998. The Analects of Confucius: A Philosophical Translation. New York: Ballantine Books.

Arunkhajornsak, Sarinya. 2007. Cosmology and Ethics in Confucianism. Doctoral dissertation, Chulalongkorn University.

Brooks, E. Bruce, and A. Taeko Brooks (trans.). 1998. The Original Analects: Sayings of Confucius and His Successors. New York: Columbia University Press.
Chan, Wing -Tsit. 1977. Syntheses in Chinese Metaphysics. In The Chinese Mind: Essentials of Chinese Philosophy and Culture, ed. by Charles A. Moore, pp. 132-148. Honolulu: University Press of Hawaii.

Cheng, Chung-ying. 1974. Greek and Chinese Views on Time and the Timeless. Philosophy East and West 24.2: 155-159.

---. 1991. New Dimensions of Confucian and Neo-Confucian Philosophy. New York: State University of New York Press.

---. 2003. Time and Timeliness (Shizhong, Shih-chung). In Encyclopedia of Chinese Philosophy, ed. by Autonio S. Cua, pp. 728-734. New York and London: Routhledge.

Cua, A. S. 1992. Competence, Concern, and the Role of Paradigmatic Individuals (chun-tzu) in Moral Education. Philosophy East and West 42.1: 49-68.

---. 2003. Junzi (Chun-tzu): The Moral Person. In Encyclopedia of Chinese Philosophy, ed. by Antonio S. Cua, pp. 329-335. New York and London: Routledge.

Hall, David L., and Roger T. Ames. 1987. Thinking Through Confucius. New York: State University of New York Press.

Hansen, Chad. 1992. A Daoist Theory of Chinese Thought: A Philosophical Interpretation. New York: Oxford University Press. 
Lau, D. C. (trans.). 1979. The Analects. [Confucius: The Analects]. London: Penguin.

---. 1970. Mencius. London: Penguin Book.

Satha-Anand, Suwanna. 2008. Lunyu: Conversing Confucius. Bangkok: Chulalongkorn University Press.

Confucous. 2003. Confucius Analects:With Selected from Traditional Commentaries. Trans. Edward Slingerland. Indianapolis and Cambridge: Hackett Publishing.

Van Norden, Bryan W. (ed.). 2002. Confucius and the Analects: New
Essays. Oxford: Oxford University.

---. 2007. Virtue Ethics andConsequentialism in Early Chinese Philosophy. New York: Cambridge University Press. Yu, Jiyuan. 2002. The Aristotelian Mean and Confucian Mean. Journal of Chinese Philosophy 29.3: 337-354.

---. 2006. Yi: Practical Wisdom in Confucius's Analects. Journal of Chinese Philosophy 33.3: 335-348.

Zhu, Rui. 2006. Kairos between Cosmic Order and Human Agency: A Comparative Study of Aurelius and Confucius. Journal of Religious Ethics 33.1: 115-138.

\section{Chinese Glossary}

$\begin{array}{ll}\text { buyi } & \text { 不義 } \\ \text { chengren } & \text { 成人 } \\ \text { dao } & \text { 道 } \\ \text { daren } & \text { 大人 } \\ d e & \text { 德 } \\ \text { ge } & \text { 戈 } \\ \text { haoxue } & \text { 好學 } \\ \text { he } & \text { 和 } \\ \text { junzi } & \text { 君子 } \\ \text { li } & \text { 禮 } \\ \text { li } & \text { 利 } \\ \text { Lunyi } & \text { 《論語》 } \\ \text { ming } & \text { 命 } \\ \text { qi } & \text { 氣 } \\ \text { quan } & \text { 權 } \\ \text { ren } & \text { 仁 } \\ \text { renren } & \text { 仁人 } \\ \text { renxing } & \text { 人性 } \\ \text { renzhe } & \text { 仁者 }\end{array}$

$\begin{array}{ll}\text { shengren } & \text { 聖人 } \\ \text { shi } & \text { 時 } \\ \text { shi } i^{\mathrm{a}} & \text { 士 } \\ \text { shizhong } & \text { 時中 } \\ \text { shui } & \text { 水 } \\ \text { tian } & \text { 天 } \\ \text { tianming } & \text { 天命 } \\ \text { wo } & \text { 我 } \\ \text { xiao } & \text { 孝 } \\ \text { xin } & \text { 心 } \\ \text { yang } & \text { 羊 } \\ \text { yi } & \text { 義 } \\ y i^{\mathrm{a}} & \text { 宜 } \\ \text { Yiching } & \text { 《易經》 } \\ \text { yinzhe } & \text { 隱者 } \\ \text { zhi } & \text { 智 } \\ \text { zhi } i^{\mathrm{a}} & \text { 知 } \\ \text { zhi } & \text { 質 } \\ \text { zhong } & \text { 中 } \\ \text { Zhongyong } & \text { 《中庸》 }\end{array}$

